\title{
THE ETHICAL DIMENSION OF JOURNALISTIC PROFESSIONALISM: VIEWS OF LITHUANIAN JOURNALISTS
}

\begin{abstract}
When evaluating the normative dimension of journalistic professionalism, researchers note that it is related to the core values of professional journalism, manifested in the recognition and application of common professional ethical principles in journalistic activities. This allows us to identify the existence of the ethical dimension of journalistic professionalism. This study examines the ethical dimension of journalistic professionalism by analysing the attitudes of Lithuanian journalists towards the importance of ethical aspects, codified in the Code of Ethics in Providing Information to the Public of Lithuania (2016) for journalistic professionalism.
\end{abstract}

Key words: journalist ethics, journalistic professionalism, code of ethics, Lithuania

\section{Introduction}

Journalistic self-regulation ensures the social responsibility of the media and creates coherent interaction between the society and the media system. Karmasin confirms the importance of journalistic self-regulation for ensuring social responsibility and states that the concept of informative self-regulation shapes the behavioural system of journalists, which is based on appropriate behaviour standards (2002: 128-130). This means that journalistic self-regulation guarantees professional journalistic activities consistent with the needs of society, justifying privileges granted by the public for journalistic activity and meeting public expectations with regard to this activity. Such a method of operation is regarded to be one of the dimensions of journalistic professionalism.

Dimensions of journalistic professionalism (cognitive, normative and evaluative dimensions) are distinguished by applying the structural-functional approach to professionalism. Larson associates the cognitive dimension with professional knowledge and techniques (1977). The evaluative dimension, according to her, describes the autonomy and qualities of the journalist's profession, whereas the normative dimension encompasses the activity of media professionals

\footnotetext{
${ }^{1}$ Received August 2021 / Accepted September 2021

2 e-mail: jolanta.mazyle@kf.vu.lt

${ }^{3}$ e-mail: marija.stonkiene@kf.vu.lt
} 
and journalists in terms of provision of public services and ethical professional practices of journalists (Larson, 1977). Singer states that the normative dimension is the most powerful in journalistic professionalism (2003). It should be noted that normative and evaluative dimensions interact: Schudson and Anderson assert that the professional code of ethics ensures internal solidarity, cohesion and importance in identifying and distinguishing professional groups from each other (2009). This suggests that the normative dimension interacts with the cognitive dimension, manifested in the knowledge and application of professional ethical standards and ethical behaviour, which allows to distinguish and separate one group of people from another group whose members are unaware of or do not apply such standards. Larson considers the ethical journalistic activity to be the application of common ethical beliefs in the daily work of journalists (1977). Therefore, when evaluating the normative dimension of journalistic professionalism, it is significant that it is related both to core values of professional journalism that have been established in the media system and to the constant recognition and application of relevant common professional ethical values in journalistic activities. These professional ethical values stem from the functions delegated by the public to the media system and public expectations; they demonstrate the commitment of journalists to the society, which is linked directly to journalistic professionalism. According to Evetts, ethical behaviour rules are codified taking into account public interests (2006). Borden ties ethical behaviour rules not only with external values, shaped by public expectations, but also with personal internal values, shaped by the individual's perception of the quality of journalistic activity (2007). These levels of values highlight the importance of the codes of ethics of journalists as they guarantee clarity, demonstrate methods of socially responsible professional activity and define principles which journalists must follow to maintain a high standard of quality in their work (Ward, 2019: 296). This means that professional codes of ethics of journalists provide guidelines for professional activity and affirm socially responsible practices of journalists, while compliance with them demonstrates journalistic professionalism. This underscores the significance of behavioural standards formed by the system itself for the recognition of professionalism and enables us to talk about the ethical dimension of journalistic professionalism. Ward's notion that the attitude towards journalistic ethics depends on key journalistic functions and activities of journalists carrying out those functions, as well as on the understanding of ethical principles that apply in professional activity (2019: 296), indicates that certain interpretations of ethical norms are possible, occurring when these norms are applied in practice. These interpretations echo the concept of internal values distinguished in ethical behaviour by Borden, which are particularly important when deciding on ethical behaviour (application/compliance with ethical standards). This shows journalists' and media professionals' views towards assessment, recognition and compliance with professional ethical standards.

When analysing the application of ethical behaviour standards in practice, it is essential to evaluate various factors that influence journalistic practices. Some of the most important among them are institutional environments or organisational 
structures, creating certain practices based on internal decisions and shaping processes. Although researchers state that anti-market elements are characteristic to journalistic professionalism (Larson, 1977; May, 2001; Ohmann, 2003), having assessed inevitable market influence, it is proposed to ensure media quality by the combination of the market, law and ethics (Bertrand, 200: 124,164). Digital technologies, creating new opportunities for news production and dissemination, also pose ethical dilemmas, at the same time changing journalistic practices, leading to a new discourse on media ethics.

The aim of the study is to determine the view of professional journalists towards the ethical dimension of journalistic professionalism. The study is based on the Code of Ethics in Providing Information to the Public of Lithuania (approved on 29 February 2016), which applies to all media outlets and journalists working for them. The study seeks not only to examine the views of interviewed journalists about the ethical dimension of journalistic professionalism, but also to identify the changing trends of professional ethical standards in journalism and factors determining the need for change in professional ethical standards.

The objectives are the following: (1) to discuss the key norms, principles and rules of the Code of Ethics in Providing Information to the Public of Lithuania, which form ethical behaviour standards in journalism; (2) to analyse the views of professional journalists about the key principles and regulations of the Code of Ethics in Providing Information to the Public of Lithuania; to determine what impact the standards of ethical journalism have on their practice and to evaluate whether ethical professional activity is regarded as a component of professionalism.

To achieve the aim of the study, an analysis of the Code of Ethics in Providing Information to the Public of Lithuania was performed and qualitative empirical research, in-depth interviews with Lithuanian journalists, was carried out.

\section{Standards of professional journalism in the Code of Ethics in Providing Information to the Public of Lithuania}

In 1995, the Seimas of the Republic of Lithuania ratified Resolution 1003 (1993) on the Ethics of Journalism adopted by the Parliamentary Assembly of the Council of Europe. Provisions of the Resolution became the foundation of the first Code of Ethics of Lithuanian Journalists and Publishers passed in 1996, which was in effect for nearly a decade. In 2005, having assessed peculiarities of the work of the media in a changing society, public sphere and with new participants emerging in the field of communication, a new version of the document was adopted: the Code of Ethics in Providing Information to the Public of Lithuania (hereinafter - the Code). The Code, which is currently in effect, consists of 7 chapters and 66 articles.

The first chapter contains provisions on ethical journalistic activities, which are essentially rules for professional practice. For instance, it establishes the journalist's obligation to provide accurate, truthful news and diverse opinions in order to ensure a person's (an individual's) right to receive truthful information. 
This chapter stipulates that news and opinions have to be clearly separated, whereas journalists, public information producers and disseminators must guarantee that opinions are expressed honestly and ethically, without distorting facts or data. The Code states that opinions provided in journalistic publications or video and audio footage must be expressed ethically. In addition, respecting the diversity of opinion, public information producers and disseminators must provide opinions of at least two people that are not interrelated when information is contradictory, unclear or is related to conflicting issues. The first chapter of the Code devotes much attention to the accuracy and reliability of content produced by journalists and media outlets (careful and critical assessment of information sources), as well as to the effort to provide information in a way that would not mislead information consumers. It is assumed that ethical provisions stated in the first chapter of the Code are directly related to high professionalism and media quality.

The second chapter of the Code is dedicated to transparency and independence of journalists, public information producers and disseminators. The main provisions of this chapter stipulate that journalists and media outlets have to be free and independent. Therefore, following provisions of the Code, a journalist has to refuse an assignment of a public information producer or a superior if it contradicts the country's laws, journalist ethics or personal beliefs. A highly topical professional ethics issue emerged in the communication field in recent decades as journalists attempt to adjust their work with activities in state or local government bodies or political parties. Hence, the Code currently in effect stipulates that such duality is incompatible with professional journalistic practice.

The third chapter of the Code covers the protection of human rights (honour and dignity, privacy etc.). Provisions of this chapter are tied directly to legal norms established in the Law on Provision of Information to the Public that describe legal violations. Presumably, in this regard the Code could be amended, as legal norms transposed into the Code do not become ethical norms a priori.

The fourth chapter of the Code discusses professional solidarity and fair competition. Unfortunately, as stated in 2018-2020 reports of the Commission of Ethics in the Provision of Information to the Public, it is an acute problem and shortcomings of editorial boards are frequent, especially in regional media.

The fifth chapter of the Code is dedicated to mutual commitments of journalists and heads of editorial boards. Provisions in question protect journalists from the potential restriction of their rights (fair remuneration for original work, the journalist's right to renounce authorship and signature if the content is fundamentally distorted when it is edited or otherwise remade). The sixth chapter discusses responsibility for violations of the Code.

In a democratic society, journalists enjoy the rights and privileges safeguarded by law, ensuring the creation of various information society media, collection of public information, dissemination of opinions and news. Speaking about the benefits of the Code of Ethics for the professional community, experts emphasise that the Code is a tool for evaluation of their professional work. 


\section{Lithuanian journalists on professional ethics}

Qualitative research, in-depth interviews with 10 Lithuanian journalists, was conducted to determine the views of journalists about the ethical dimension of journalistic professionalism. The main selection criterion was professional experience (at least 5 years of experience), whereas media outlets and legal bases for their activities were not evaluated. Informants (I1-I10) were selected using a snowball sampling technique. Interview participants have substantial journalistic experience, ranging from 5 years to over 50 years ${ }^{4}$. Informants were asked 5 questions striving to ascertain: views of interviewed professional journalists on links between professional ethical standards and media accountability, journalists' social responsibility and protection of the public interest (Q1), ethical aspects of activity of the professional journalist in the public sphere in contrast to other participants of the communication field providing information in the public sphere (influencers, public relations experts etc.) (Q2), importance of ethical aspects of activity for the journalist's professionalism and evaluation of one's quality of work (Q3), influence of media outlets on compliance with ethical standards, causes of violation of ethics (Q4) and influence of journalistic practice on views about professional ethical standards (Q5). The duration of interviews (conversations) was 40-180 minutes. Interviews were conducted during May to July 2021.

Interviewed media professionals understand professional activity first as protecting the public interest (I2), stressing that "only a journalist who complies with ethical standards protects the public interest, instead of satisfying curiosity" (I2). A direct link is thus highlighted between the ethical dimension of journalistic professionalism and the protection of the public interest, media accountability (I8, I9, I10). An interviewee notes, "It is impossible to be socially responsible if one does not adhere to professional ethical standards of journalists. Social responsibility is inseparable from the freedom of speech, whereas the freedom of speech places much responsibility on journalists - without adherence to professional ethical standards of journalists, the freedom of speech may gain some very negative features" (I4). The importance of ethical journalistic activity is linked to media accountability and is guaranteed by avoiding the conflict of interests (I3), meanwhile, the strive for protection of the public interest, problem solving and development of good practices is linked to social responsibility (I3). One of the respondents underscores, "Our professional ethical standards are directly related to social responsibility, media accountability and protection of the public interest" (I6). This direct connection is explained by stating that professional ethical standards of journalists " [...] represent a highly significant expression of traditions, customs and expectations not only of the community of professionals but also of the society" (I6). Opinions of interviewees indicate that ethical aspects of professional journalism are vital for carrying out the role of the media as a defender of the public interest and are also significant for

${ }^{4}$ I1: 5 years; I2:49 years; I3: 7 years; I4: 36 years; I5: over 50 years; I6: 30 years; I7: 25 years; I8: 12 years; I9: 22 years; I10: 6 years. 
media accountability and social responsibility. However, as the media acts in the public interest, it is crucial not to abuse the power of the media. If boundaries are overstepped in relation to the protection of the public interest and the abuse of power, then trust in the work of journalists is undermined, media accountability is distorted and social responsibility is eliminated. To describe the consequences of the abuse of power by the media, one respondent used a metaphor of a watchdog replaced by a fighting dog, "Nobody wants to have anything to do with it, although it is feared, yet it is not respected, it is not liked and is sought to be at the very least disciplined. Unsurprisingly, few would entrust a dog that does not understand the rules of the role of a watchdog" (I6).

Furthermore, research participants also drew attention to the negative impact of market relations on media accountability and social responsibility: "[...] everything depends on the media owner. A certain clan, or perhaps clans, of media 'sharks' thrive in Lithuania [...]" (I2). [...] Our media business is still not typically socially responsible and because of this I do not think it can be said that the media is also accountable. But this is a matter of debate and understanding, perception" (I9). Deconstructing the definition of social responsibility, one more issue was pointed out - the bias of journalists, which prevents them from being fully accountable to the public (I4). Opinions of interviewees confirm the insights of Borden (2000) and Bertrand (2000) that market relations and the interaction with the political government are the key factors affecting ethical activities of the media, striving to protect the public interest.

Assessing the ethical aspects of entities engaged in the provision of information in the public sphere, interviewees underscored that ethical activity is important for everyone that produces and disseminates public information (I4, I5, I9). At the same time, it was noted that the ethical aspects of journalistic activity have definite distinctions: "The activity of professional journalism is inseparable from the consequences of compliance/non-compliance with moral, ethical professional norms [...]" (I1), journalists "are more obliged by the code of ethics" (I2). Interviewees believe that ethical behaviour is the most characteristic activity of professional journalism (I6, I9). Although they say other subjects operating in the public sphere are also expected to meet ethical standards, yet ethical behaviour of journalists is exceptionally important - ethical activity of journalists distinguishing them from other participants of the public information field is explained by their accountability to the public, objectivity, impartiality, fact checking and presentation of various opinions (I4, I6, I7). Media accountability to the public is used as an argument to underline the importance of ethical behaviour of journalists as it is stated that other participants of the public information field "[...] often perform the function of advertising or promoting" (I3) and "[...] are not committed to providing actual facts to the public. They work for a customer but are not accountable or committed to the public" (I4). Interviewees in particular separated the ethical aspects of influencers' activity, whose activity is not regulated by law so far (even though some professional journalists and editors are also engaged in this, with interviewees providing specific examples). 
Clearly distinct goals and operation principles of participants in the public information field reveal different ethical aspects of activity - journalistic activity emphasises objectivity, reflection of various opinions and versatility, which show that journalists act in the public interest and distance themselves from interests of separate individual groups. When the activity is in the public interest, the study has revealed a strong tendency to strive for goals important to the public, linked to appropriate ethical commitments. Interviewees view this to be a significant and exceptional trait of professional journalism.

All of the interviewed professional journalists named objectivity, impartiality and diversity of opinion as crucial ethical principles of journalistic activity. Other ethical principles identified as important were: avoidance of conflict of interest, maintaining confidentiality, respect of personal rights (I3), perfect knowledge of the Lithuanian language (I2, I7), critical thinking (I8), communication culture, respect (I4, I9), accuracy, honesty (I10) and quick reaction (I8). The opinion of respondents coincided with the view that the adherence to ethical standards is vital for high quality work (I4, I5, I7).

Interviews confirmed the observations of researchers regarding the connection between ethical commitments of journalists to the society and journalistic professionalism (Larson, 1977, Evetts, 2006). Several respondents contemplated the profession of the journalist and the ambiguity of professionalism: "[...] people no longer know what a professional journalist is" (I6), "[... in Lithuania anyone can be a journalist, requirements for education and knowledge do not apply. Such lenient legal provisions relieve from responsibility everyone who works in the media or cooperates with it" (I9). These attitudes unveil the particularities of journalistic professionalism: the cognitive dimension distinguished by Larson (1977) can be formed on the basis of professional practice, yet in the opinion of journalists themselves this is insufficient for "separating" the profession of the journalist. Several interviewees expressed an opinion that the cognitive dimension based on practical activity is accompanied by a weaker ethical dimension of journalistic professionalism. This insight should be verified by quantitative research. It is obvious that the communality of journalists, as well as support and enhancement of the foundations of their focused activities based on values are important for the ethical work of journalists.

Assessing the potential influence of a media outlet on ethical aspects of professional journalism activity, interviewees stressed the significance of ethical principles in professional practice: "[...] ethical principles are very important to me, regardless of what media outlet I work for" (I1), [...] the editorial board knew that I had not and would not make compromises with my conscience" (I2), "personally, I am very serious and honest about professional ethics [...] I would never work for an unethical paper" (I4), "[...] the journalist always has the right to choose whether to agree to demands or follow the norms of decency and ethics. One can always quit from such [an unethical] paper" (I5). Clearly, respondents accentuated the importance of following internal values concerning ethical norms, which indicates that internal values determine the level of ethical activity.

Moreover, opinions were also expressed about the ethical aspects of media organisations activity and the recognition of their importance: "in my working 
environment much attention is devoted to the issue of journalistic ethics $[\ldots]$ " (I3), "[...] the editorial board I work for, regardless of it being interested in a quick reflection of events, pays much attention to verifying information" (I8). Negative influence of media organisations on ethical aspects was also pointed out: "[...] media outlets, more precisely their editors, often attempt to shape the media outlet's position" (I5), "[...] media outlets, their owners, have much influence on professional activity, speaking about working conditions that are created and views of ownership [...]. Earlier, the job of journalists was easier from the standpoint of freedom. What has had a negative impact, among other things, is the emergence of a big trend of public relations - we no longer hear first-hand news, [instead] polished news, coordinated press releases are provided [...]" (I6). This indicates that the changing media ecosystem and emerging new players have an effect on the ethical activity of professional journalists, which means that the activities of other public information disseminators, replacing journalists' activities, may determine the need for new ethical standards.

Speaking about the impact of journalistic practice on their views towards professional ethical standards, interviewees expressed two kinds of opinions. On the one hand, "[...] journalistic practice helps to better grasp the importance of ethical principles in reality" (I1). On the other hand, it is thought that editorial boards may have influence, too: "[...] some editorial boards may be manipulating this. Certain 'achievers' emerge in editorial boards and start writing some sort of biased articles [hit pieces, puff pieces] or even [biased journalistic] investigations" (I2), "[...] this depends on a publication, editor's demands and circumstances" (I4), "[...] colleagues who come to terms with demands, more precisely adapt to them, save jobs" (I5). Obviously, interviewees put emphasis on the impact of the institutional environment on professional ethical activity; internal decisions of organisational structures create specific professional practices and shape their ethical aspects. This gives rise to different ethical levels of professional practice in individual organisational environments ("ethics of editorial boards or media owners"), which are linked to market influence.

Interviewee insights confirmed the conclusions provided in research resources about the subjects that pose challenges to professional ethics of journalists, i.e., business and political government. Violations of ethical standards named by interviewees may be classified into several groups: market impact (related to popularity or clickbait (I2, I3, I4, I6, I7), satisfaction of audience's curiosity (I3), competition (I7)); political influence (I6, I7, I8); the journalist's work, status and activities ("due to urgency" (I4), "[...] some well-known journalists do so [...]" (I6), "a sense of self-esteem" (I5), "[...] many journalists have also become influencers in the public sphere, on social networks [...]" (I8); indulgence in the media power (I7, I8). Interviewees associate more effective application of ethical standards with better self-regulation, improved operation of ethics supervision bodies and identical approach to all violations of ethics that are committed (I6).

Remarks by research participants about the changing social environment culture, public tolerance and influence of the community of journalists on professional 
aspects of the journalist's work - are also significant. For instance, in the opinion of interviewees: "[...] some provisions seem to have become universally unimportant [...]" (I5), "[...] much has changed, now there is more tolerance for nonsense" (I9), "life does not stand still and some norms sometimes simply become irrelevant, whereas others, on the contrary, become highly important for the public [...] it has become important for journalists working in a media outlet to reveal their ties [to businesses], especially when writing about competing companies" (I7). Opinions of interviewees do not indicate that there are major discrepancies between the needs of journalistic practice and professional journalistic ethics, nor do they imply that there are critical contradictions or the necessity for radical change.

\section{Conclusion}

The qualitative research, interviews with Lithuanian journalists, has revealed that the ethical dimension is distinguished in journalistic professionalism. Interviewees believe that the ethical aspects of professional journalism are crucial for the implementation of the role of the media as a defender of the public interest and are significant for media accountability and social responsibility. The ethical aspects of professional activity, social functions of the media and journalistic responsibility are tied directly to journalistic professionalism.

According to research participants, all entities operating in the public sphere must meet appropriate ethical requirements, yet ethical activity of journalists is exceptional due to their professional mission to protect the public interest. The goal to protect the public interest validates media accountability and social responsibility and gives prominence to the key ethical professional principles of journalism objectivity, impartiality and plurality of opinion - as identified by interviewees. Interviewees have identified these principles as the key ethical principles by revealing their internal professional values. Interviewees consider that these principles can be viewed as the ethical aspect distinguishing the activities of journalists from other subjects operating in the public sphere.

Interviewees believe that compliance with ethical standards demonstrates the quality of journalistic work and journalistic professionalism. Ethical standards establish and affirm the reliability of the journalist that is essential for public trust in the media. This is one of the indicators of the quality of journalistic work and journalistic professionalism.

The analysis of opinions of research participants shows that the changing media ecosystem, new players emerging in the public sphere and in the communication field affect the ethical behaviour of journalists. This suggests that journalistic professionalism is also accompanied by the changing ethical dimension. Any need for change of professional ethical standards of journalists is related to an ongoing shift in the society and the public sphere, as well as to novelties that come via social media. When updating the codes of professional ethics of journalists, it is vital to minimise the negative influence of the institutional environment and the market on 
the media, thus guaranteeing the reliability of the media in terms of protecting the public interest.

The important factors that have an effect on ethical activity of the media when protecting the public interest, in the opinion of interviewees (which also corresponds to the factors identified in scientific resources), are law, market and relationships with the political government. Research participants indicated that the institutional environment also influences ethical activities of the journalist by forming institutional practices of ethical behaviour (either ensuring ethical professional activity or encouraging and downplaying unethical activity). In that context the level of individual ethical professional activity, which is based on the journalist's internal values, gains exceptional significance.

\section{References}

Bertrand, Claude Jean (2000). Media ethics \& accountability systems. New Brunswick, N. J.: Transaction Publishers.

Borden, S. L. (2000). A model for evaluating journalist resistance to business constraints. Journal of Mass Media Ethics, (15) 3, pp. 149-166. DOI 10.1207 S15327728JMME1503-2.

Evetts, J. (2006). Short note: The sociology of professional groups: New directions. Current sociology, (54) 1, pp. 133-143. DOI 10.1.1.825.550\&rep=rep1\&type=pdf.

Karmasin, M. (2002). Medien und Ethik. Stuttgart: Philipp Reclam.

Larson, M. S. (1977). The rise of professionalism: A sociological analysis. Berkeley: University of California Press.

Lietuvos visuomenès informavimo etikos kodeksas: patvirtintas viešosios informacijos rengèju ir skleideju organizaciju ir Visuomenès informavimo etikos asociacijos nariu atstovu $2016 \mathrm{~m}$. vasario 29 d. susirinkime $=$ Code of Ethics in Providing Information to the Public of Lithuania. TAR, 2020-05-18, Nr. 10556.

May, W. F. (2001). Beleaguered Rulers: The Public Obligation of the Professional. Louisville, London: Westminster John Knox Press.

Ohmann, R. (2003). Politics of Knowledge: The Commercialization of the University, The Professions, and Print Culture. Middletown, CT: Wesleyan University Press.

Schudson, M., Anderson, C. (2009). Objectivity, professionalism, and truth seeking in journalism. In The handbook of journalism studies/ Ed. K. Wahl-Jorgensen \& T. Hanitzsch. (pp.88-101). New York: Routledge.

Singer, J. B. (2003). Who are these guys? The online challenge to the notion of journalistic professionalism.Journalism, no. 2, 139-163. DOI: 10.1177/146488490342001

Ward, S. J. (2019). Journalism ethics. In The handbook of journalism studies (pp.307323), Routledge. 


\title{
ETIČKA DIMENZIJA NOVINARSKOG PROFESIONALIZMA: STAVOVI LITVANSKIH NOVINARA
}

\begin{abstract}
Apstrakt: Prilikom procene normativne dimenzije novinarskog profesionalizma, istraživači mogu primetiti da se ova dimenzija odnosi na osnovne vrednosti profesionalnog novinarstva, koje se manifestuju u prepoznavanju i primeni određenih zajedničkih profesionalnih etičkih principa novinarske profesije. Ovo omogućava prepoznavanje etičke dimenzije novinarskog profesionalizma. U studiji se etička dimenzija novinarskog profesionalizma analizira ispitivanjem stavova litvanskih novinara o važnosti etičkih aspekata novinarskog profesionalizma, kodifikovanih $u$ vidu Etičkog kodeksa o pružanju informacija javnosti Litvanije (2016).
\end{abstract}

Ključne reči: novinarska etika, novinarski profesionalizam, etički kodeks, Litvanija 